\title{
Regional Climate Change and Impact Assessment for the Federal State Hesse, Germany, and Implications of the Global $2{ }^{\circ} \mathrm{C}$ Climate Target
}

\author{
H. Huebener ${ }^{1}$, S. Baumgart ${ }^{2}$, N. Jansky ${ }^{3}$, \\ F. Kreienkamp ${ }^{2}$, A. Spekat ${ }^{2}$ and H.Wolf ${ }^{1}$ \\ ${ }^{1}$ Hessian Agency for Environment and Geology, Wiesbaden \\ ${ }^{2}$ Climate \& Environment Consulting GmbH, Potsdam \\ ${ }^{3}$ Hochschule RheinMain, Univ. of Applied Sciences, Rüsselsheim \\ Hessian Agency for Environment and Geology, Wiesbaden
}

Germany

\section{Introduction}

\subsection{Background}

While climate change is a global problem, the impacts as well as mitigation and adaptation measures are local and require local and regional stakeholders to act accordingly. Thus, there is an ever increasing demand to provide climate change information with high resolution for impact assessment and regionally tailored mitigation and adaptation actions. The environmental agency of the federal state of Hesse, Germany, is tasked to provide the scientific background for regional governmental bodies, local economy and the general public. The most recent development on the political agenda regarding climate change is the global political target of limiting climate change to not more than $2{ }^{\circ} \mathrm{C}$ above the pre-industrial level. In December 2010 the United Nations Framework Convention on Climate Change (UNFCCC) agreed on this goal at the $16^{\text {th }}$ Conference of the Parties (COP16) to avoid the most dangerous and possibly irreversible impacts of climate change (UNFCCC, 2011). In the meantime, countries are preparing for adaptation to the expected impacts of climate change. For example, Germany has decided its Adaptation Strategy in December 2008 (Bundesregierung, 2008). Now it is the responsibility of the federal states to put this strategy into adaptation measures and into concrete action.

While the feasibility of the $2{ }^{\circ} \mathrm{C}$ climate target is quite uncertain and will require a concerted and ambitious mitigation policy from all states, the climate change and associated impacts that are projected under the $2{ }^{\circ} \mathrm{C}$ target can be considered the un-avoidable changes society has to face. For political and economic decisions that account for climate impacts a thorough assessment of the regional implications of the global $2{ }^{\circ} \mathrm{C}$ target is necessary. Here, we will present the climate change in Hesse that would occur under the global $2{ }^{\circ} \mathrm{C}$ target using two different analysis methods, i.e., dynamical downscaling and empirical statistical downscaling. We will compare their results to the regional climate change that would occur under the IPCC 
Special Report on Emission Scenarios (SRES; Nakićenović et al., 2000) A1B scenario, which more or less resembles the current emissions. From this comparison we assess the regional climate change that can be avoided if the necessary mitigation actions were realized to shift from the current emission path to a low-emission path for keeping the $2{ }^{\circ} \mathrm{C}$ target.

In the EU FP6 Project ENSEMBLES a scenario, known as E1, was developed that follows an emission path which eventually leads to a $\mathrm{CO}_{2}$-equivalent concentration of $450 \mathrm{ppm}$, a level which is considered to provide a more than $50 \%$ chance of limiting global warming to $2{ }^{\circ} \mathrm{C}$ (Johns et al., 2011). Therefore we will present results from an assessment for the climate change under the $2{ }^{\circ} \mathrm{C}$ target and compare it with the projected changes under the A1B scenario.

\subsection{The global $2{ }^{\circ} \mathrm{C}$ target}

At the COP16 of the UNFCCC held 2010 in Cancun, Mexico, it was agreed "... to hold the increase in global average temperature below $2{ }^{\circ} \mathrm{C}$ above pre-industrial levels ..." (UNFCCC, 2011). As pointed out by Randalls (2010), who traced the origins and the development of the $2{ }^{\circ} \mathrm{C}$ target, this was a milestone in a process of growing awareness that there is a "... maximum allowable warming to avoid dangerous anthropogenic interference in the climate. "

Whereas in the 1970s and 1980s the prevailing approach was to consider carbon emissions merely as a pollutant, publications such as Bach (1980) underlined the necessity that climate policy should be based on an assessment of the risks of climate change. There was dispute over the magnitude of tolerable change, whether it should be constrained to a temperature rise of $0.1{ }^{\circ} \mathrm{C}$ per decade or to a stabilization of the global temperature on a higher level. Rijsberman \& Swart (1990) introduced the notion of a temperature rise that should not surpass a mark of $2{ }^{\circ} \mathrm{C}$ above the pre-industrial level. The German Advisory Council on Global Change (WBGU, 1995) performed important groundwork concerning aspects such as the identification of a tolerable window for the temperature development which is corroborated by the climate fluctuations of the present geological epoch as well as addressing the question of adaptation costs.

Basically, the $2{ }^{\circ} \mathrm{C}$ target is designed to avoid the most dangerous climate impacts. WBGU (1995) states the "preservation of creation" and "prevention of excessive costs" as the boundary conditions for which this target was developed. While even at a global warming below $2{ }^{\circ} \mathrm{C}$ impacts of climate change on ecosystems and society cannot be excluded, it is believed that below the $2{ }^{\circ} \mathrm{C}$ threshold some dangerous climate change can be avoided. In the third assessment report of the IPCC, a diagram summarizes the "reasons for concern" with respect to different levels of global mean temperature change relative to the 1990 level (IPCC, 2001, Fig 19-7). The figure was updated by Smith et al. (2009), showing even greater reasons for concern.

Previous simulations aiming at keeping the $2{ }^{\circ} \mathrm{C}$ target have either used stabilization scenarios (e.g., May, 2008) or were started from the SRES B2 scenario (Meinshausen et al., 2006; van Vuuren et al., 2007). Since current atmospheric $\mathrm{CO}_{2}$ concentrations are clearly above the SRES B2 path (Le Quéré et al., 2009), both approaches seem questionable. In the framework of the EU-funded project ENSEMBLES (van der Linden \& Mitchell, 2009) a mitigation scenario was developed that provides a plausible socio-economic path towards keeping the $2{ }^{\circ} \mathrm{C}$ target. The scenario starts from the SRES A1B scenario and aims at stabilizing atmospheric $\mathrm{CO}_{2}$-equivalent concentrations at $450 \mathrm{ppm}$, while allowing a slight overshoot over this level around the middle of the current century. This scenario is called E1 (Lowe et al., 2009). A more detailed description of the scenario construction and global mean results for temperature, precipitation, and the carbon cycle feedbacks can be found in Johns et al. (2011). 
For the planning of mitigation and adaptation measures, it is relevant to know how much of the projected climate change might be avoided due to mitigation actions and which part of climate change might occur even under the $2{ }^{\circ} \mathrm{C}$ target and therefore calls for adaptation. Because the goal refers to a global mean temperature increase, it is necessary to deduce what the impacts would be regionally.

It should be mentioned that there is debate in the scientific community on the feasibility of the $2{ }^{\circ} \mathrm{C}$ target. Randalls (2010) points out that (i) it is established in the context of large uncertainties about climate sensitivity, (ii) there is insufficient clarity on the damage costs and (iii) researchers interested in science-policy dynamics have critiqued it for forcing a rather tenuous policy debate that has detracted from the process of reducing emissions.

However, the $2{ }^{\circ} \mathrm{C}$ target can serve as a focus point to assess the possible gains (in terms of avoided impacts) of ambitious mitigation actions. For governmental and economic bodies this is a central argument on whether or not mitigation actions are put into place. Moreover, it has been consented to on a broad international basis and will be a major factor in climate change negotiations.

\subsection{Climate change assessments in the federal state Hesse}

As a typical regional stakeholder, the federal state Hesse in central Germany has instigated regional climate change assessments and climate impact research on the issues relevant for the regional economy and ecology since the year 2004. In two frameworks ("INKLIM2012" and "INKLIM2012 Baustein II plus") several projects were realized.

Already detectable climate change in Hesse shows that the annual mean warming from 1951 to 2000 was $0.9^{\circ} \mathrm{C}$ (Schönwiese et al., 2005), thus larger than the global average for this period of about $0.7^{\circ} \mathrm{C}$ (IPCC, 2007). This is accompanied by an increasing number of heat days (daily maximum temperature $\geq 30^{\circ} \mathrm{C}$ ) in the summer months, particularly in August, and a decrease of frost (daily minimum temperature $<0{ }^{\circ} \mathrm{C}$ ) and ice days (daily maximum temperature $<0{ }^{\circ} \mathrm{C}$ ) in winter and spring (Schönwiese et al., 2006). Furthermore there is already a detectable tendency in Hesse for dryer summers and wetter winters (Schönwiese et al., 2005), with an increase in the number and duration of dry spells in summer (Schönwiese et al., 2006).

These tendencies are also projected for future climate change in central Europe (IPCC, 2007). Furthermore there are results for the state of Hesse from an analysis of high resolution regional climate model projections for several SRES-Scenarios (Nakićenović et al., 2000) using both, empirical statistical (ESD) and dynamical (RCM) methods (Federal State of Hesse, 2011). An assessment of likely future temperature change for Hesse in conjunction with the $2{ }^{\circ} \mathrm{C}$ target can be found in Kreienkamp \& Spekat (2009).

The analyzed future climate impacts for water management (groundwater and its use for irrigation and household demand as well as flood and low-flow conditions in rivers) show an increasing demand for irrigation water during the growing period (Berthold \& Hug, 2008), combined with increasing flood risks during winter and increasing low-flow situations during summer (Brahmer et al., 2008) in the analyzed parts of Hesse.

The projected changes in temperature and precipitation have consequences for agriculture, forestry, fruits, vine, and natural ecosystems. In all these sectors the vulnerabilities of the respective systems are assessed, highlighting possible impacts. The goal of the impact research projects is to assess the risks and to develop possible adaptation strategies for each sector. A further focus of research projects is on the impacts of climate change on the health sector. 


\subsection{Goals of this chapter}

The goals of this chapter are to:

(a) Assess the magnitude of regional climate change impacts in Hesse under a global $2{ }^{\circ} \mathrm{C}$ target from time slices of higher emission scenarios (IPCC SRES A1B, A2 and B1), for the time frame when the global $2{ }^{\circ} \mathrm{C}$ target is breached, using one GCM and two RCMs and one ESD.

(b) Assess the regional results for Hesse for the end of the century in one ENSEMBLES E1 simulation.

(c) Provide an estimate of avoidable regional climate change in Hesse from comparison of results for a higher emission scenario (A1B) to the results for the $2^{\circ} \mathrm{C}$ target.

The methodologies are in principle applicable in any region of the world. Since RCM and ESD simulations are not available in all regions, some useful hints for the interpretation of the global results can be gained from the analyses shown in this chapter.

In Section 2 we present the data and methods used. Section 3 presents the results from different types of analyses. The first step is to determine what the local or regional temperature increase would be, if the global temperature would rise by $2{ }^{\circ} \mathrm{C}$ (Subsections 3.1 to 3.4). In Subsection 3.5, the E1 scenario (Lowe et al., 2009) is analyzed for the region of Hesse, which aims at keeping the $2{ }^{\circ} \mathrm{C}$ target for the end of the current century. Avoidable climate change for this time frame is assessed from the difference between results from the E1 scenario and a higher emission scenario (SRES A1B) in Subsection 3.6. A summary of the presented findings and some conclusions form the final Section 4.

\section{Data and methods}

The data used for this study encompass one global climate model (GCM), two dynamical regional climate models (RCM) and one empirical statistical downscaling (ESD) method. All are briefly featured below.

Global climate model ECHAM5: The global mean pre-industrial temperature level is derived from three historical runs of ECHAM5/MPI-OM (Roeckner et al., 2003; 2004), henceforth abbreviated as ECHAM5. Future temperature levels are determined by ECHAM 5 runs, forced by SRES emission scenarios A1B, A2 and B1. Furthermore, global climate model results are used to force the RCMs COSMO-CLM and REMO as well as the ESD method WETTREG (all described further below) in order to obtain regional climate projections and to assess regional climate signals, as presented in Subsection 3.4. For the assessment of climate change in conjunction with the $2{ }^{\circ} \mathrm{C}$ target (Subsection 3.5) results of a GCM forced with the E1 scenario are analyzed. Since there are no ECHAM5 E1 runs, the E1 runs of the derived model version ECHAM5C (which includes a carbon-cycle sub-model) is used for this purpose, employing WETTREG to obtain a regional climate projection for Hesse. In Subsection 3.6 the analysis is then extended to ECHAM5C forced by E1 and the SRES scenario A1B, downscaled again by WETTREG, to enable an intercomparison of climate signals as they are derived by an identical GCM-downscaling cascade.

Regional dynamic climate model COSMO-CLM: Initially known as CLM, the Consortium for Small Scale Modelling (COSMO) model CCLM is nested into a global climate model (Böhm et al., 2006; Rockel et al., 2008). CCLM is a non-hydrostatic model. For Subsection 3.4 of this study the initializing and the boundary conditions are prescribed by ECHAM5 and it is applied to obtain regional climate information for the state of Hesse at the period when the global temperature increase has reached $2{ }^{\circ} \mathrm{C}$. The so-called consortium runs, data stream 3 , 
of CCLM with $0.22^{\circ}$ resolution are used (at a latitude of $55 \mathrm{~N}$ this resolution amounts to about $22.2 \mathrm{~km}$ in meridional direction and $12.7 \mathrm{~km}$ in zonal direction).

Regional dynamic climate model REMO: The Regional Model (REMO) is a further high resolution climate model that is nested into a global climate model (Jacob et al., 2008; Jacob \& Podzun, 1997). REMO is a hydrostatic model. For Subsection 3.4 of this study the initializing and the boundary conditions are as well prescribed by ECHAM5 and it is applied to obtain regional climate information for the state of Hesse at the period when the global temperature increase has reached $2{ }^{\circ} \mathrm{C}$. The so-called UBA runs of REMO (Jacob et al., 2008) with $10 \mathrm{~km}$ resolution are used.

Empirical statistical downscaling method WETTREG: The ESD method WETTREG (German: Wetterlagen-basiertes Regionalisierungsverfahren. English: Weather pattern-based regionalization method) relies on the ability of global models to reproduce the circulation regime well and statistically derives a transfer function which links regional and large-scale climate (Enke et al., 2005a;b; Spekat et al., 2010). In order to develop the transfer functions, WETTREG requires surface climatological data (for this study, climate measurements from stations in and around the State of Hesse are used, provided by the German Weather service DWD), upper air climatological data (here, reanalyses from NCEP/NCAR are used, cf. Kalnay et al., 1996), re-simulations of the current climate and projections of a future climate which are provided by the GCMs ECHAM5 and ECHAM5C. WETTREG produces a set of ten equally valid, stochastically derived, climate projections. The analyses in Subsection 3.4 are based on WETTREG2006 (Spekat et al., 2007) which is available for runs forced by ECHAM5 A1B, A2 and B1 scenarios. The analyses in Subsections 3.5 and 3.6 are based on the updated method WETTREG2010 (Kreienkamp et al., 2010) which is available for runs forced by ECHAM5 A1B, ECHAM5C A1B and ECHAM5C E1.

As described in Subsection 3.1 the first task is to determine the pre-industrial temperature level from three historical runs of ECHAM5. Then, as shown in Subsection 3.2, for each of the ECHAM5 projections that are forced by SRES emission scenarios, the time is determined in which a global mean temperature rise of $2{ }^{\circ} \mathrm{C}$ above this level occurs and a period of 30 years around it is defined. The next step, documented in Subsection 3.3, uses global model projections to address the question which continental-scale temperature increase is occurring at the time frame when the global temperature rise amounts to $2{ }^{\circ} \mathrm{C}$. The applied procedure to assess this temperature increase was developed on behalf of the Hessian Agency for Environment and Geology by the company Climate and Environment Consulting (CEC) Potsdam GmbH. It is straightforward, easy to apply, and computationally inexpensive. This analysis is followed by a dynamical and statistical downscaling study, described in Subsection 3.4, carried out to determine, which regional temperature rise will occur in the State of Hesse during the time of a global $2{ }^{\circ} \mathrm{C}$ increase. The ensuing Subsection 3.5 includes an analysis of the regional temperature signal that occurs in conjunction with the E1 scenario, forcing the GCM ECHAM5C, for the end of the $21^{\text {st }}$ century. Finally, in Subsection 3.6, a comparison between results obtained by applying the ESD method WETTREG to ECHAM5C forced by A1B or E1 for the end of the $21^{\text {st }}$ century is carried out.

Please note that results from the RCMs and the ESD in the subsequent subsections are displayed as changes relative to the time period 1971-2000. Since there are no pre-industrial simulations, an assessment of the temperature changes relative to the pre-industrial time needs to take an offset of $0.5{ }^{\circ} \mathrm{C}$ into account for the warming that was realized between 1860-1889 (pre-industrial time) and the reference period 1971-2000 (see Subsection 3.1). Global simulations used in this study are freely available for research purposes at the German Climate Data Centre (www.mad.zmaw.de/projects-at-md/ensembles/). 


\section{Results and discussion}

\subsection{Determining the global pre-industrial temperature level}

For the time 1860-2000, the global annual mean temperature is determined for the three historical runs of ECHAM5. The temperature development is shown in Fig. 1 which also includes curves of 30-year moving averages.

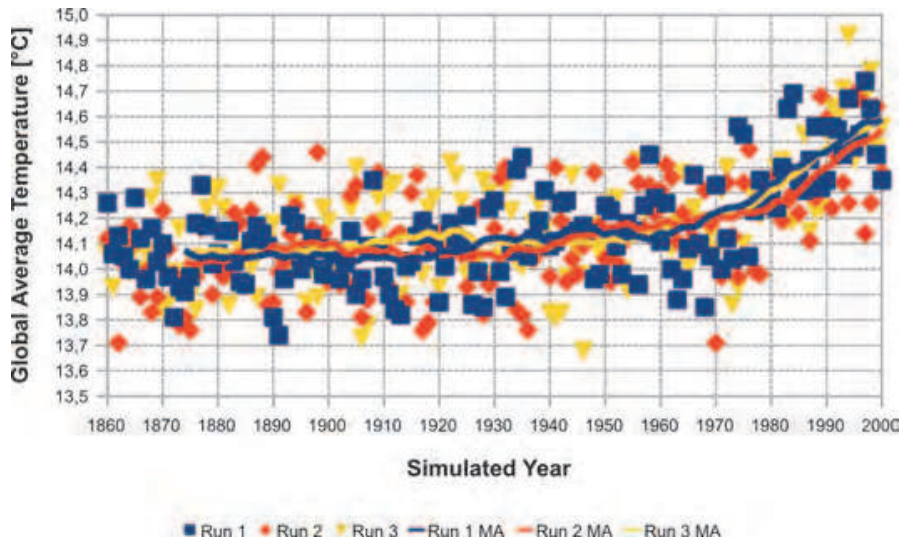

Fig. 1. Global annual mean temperature from three historical runs of the GCM ECHAM5 from 1860 to 2000 (triangles and squares). Lines show 30-year moving averages (MA).

From this analysis global temperature levels between $14.03{ }^{\circ} \mathrm{C}$ and $14.07^{\circ} \mathrm{C}$ are found for the period 1860-1889 in the three ECHAM5 historical runs, which is assumed to be indicative of the pre-industrial time. The two-digit precision of the above temperature values is a by-product of the averaging over a set of 30 values and should not be mistaken for the accuracy with which global average temperature values can be assessed. In subsequent stages of the analysis an interval between 14.0 and $14.1^{\circ} \mathrm{C}$ is used for the pre-industrial global average temperature.

Moreover, differences between the periods 1860-1889 and 1971-2000 can be inferred. These are between $0.27^{\circ} \mathrm{C}$ and $0.37^{\circ} \mathrm{C}$, depending on the individual historical runs of ECHAM5. This is in broad accordance with Trenberth et al. (2007) who give an assessment of the temperature increase on the order of $0.5^{\circ} \mathrm{C}$ for the respective time frame.

This means that about half a degree Celsius (in ECHAM5 $0.3-0.4^{\circ} \mathrm{C}$ ) of the increase specified in the $2{ }^{\circ} \mathrm{C}$ target has already occurred from the pre-industrial time to the end of the $20^{\text {th }}$ century which means that a global increase of less than $1.5^{\circ} \mathrm{C}$ over the $21^{\text {st }}$ century would be necessary to keep the $2{ }^{\circ} \mathrm{C}$ target.

\subsection{Determining the time horizon of a global $2{ }^{\circ} \mathrm{C}$ increase}

To begin with, the global average temperature for each year from 2001 to 2100 is computed from ECHAM5 projections forced with SRES emission scenarios A1B (two runs), A2 (one run) and B1 (two runs), as shown in Fig. 2.

Clearly, projections forced by scenarios A1B and A2 exhibit a higher temperature response compared to the ECHAM5 projections that are forced by the B1 scenario.

Fig. 3 zooms in on the period 2040-2080, i.e., the vicinity of the time frame when a global mean increase of $2{ }^{\circ} \mathrm{C}$ above the pre-industrial level (cf. Subsection 3.1) is expected in the GCM simulations. The temperature interval 16.0 to $16.1{ }^{\circ} \mathrm{C}$ is indicated by the grey band - 


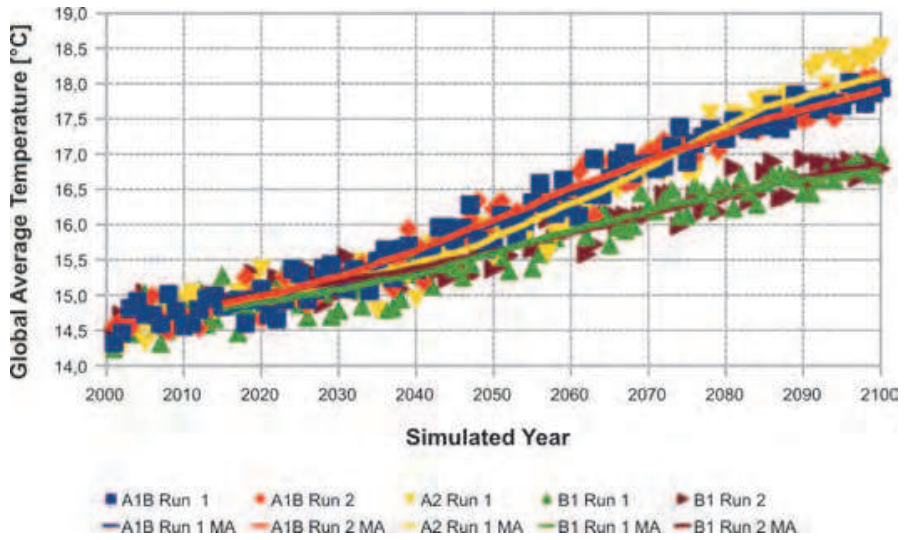

Fig. 2. Global annual mean temperature from five SRES scenario runs for A1B (2 runs), A2 (1 run) and B1 (2 runs) of the GCM ECHAM5 for the years 2001-2100 (triangles and squares). Lines show a 30-year moving average (MA).

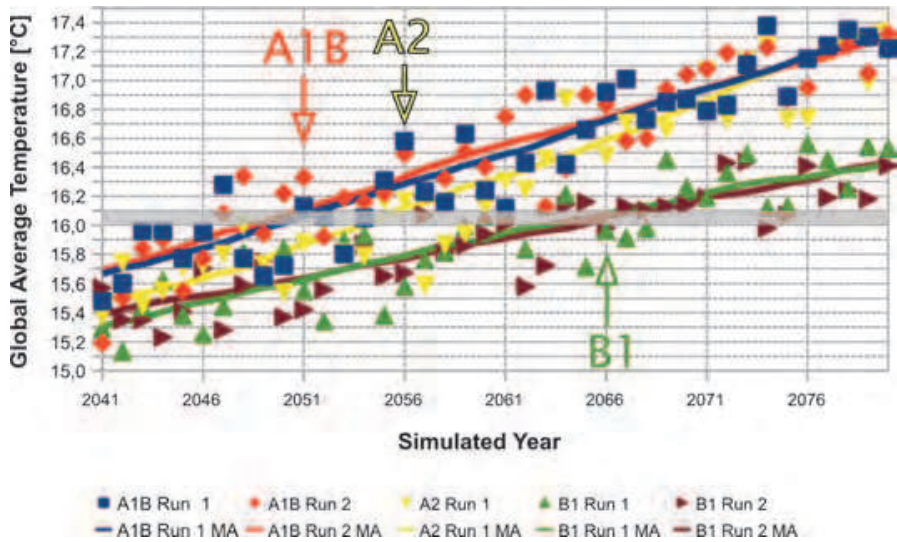

Fig. 3. As in Fig. 2, but zooming in on the time interval 2041-2080. The grey bar indicates the level of $2{ }^{\circ} \mathrm{C}$ temperature increase above pre-industrial time, arrows show time, when this level is breached by the simulations for different scenarios.

marking the level of $2{ }^{\circ} \mathrm{C}$ above the pre-industrial temperature of 14.0 to $14.1^{\circ} \mathrm{C}$, as assessed in Subsection 3.1 and defined in the $2{ }^{\circ} \mathrm{C}$ target.

The following time frames can be associated with a global mean temperature increase of $2{ }^{\circ} \mathrm{C}$ compared to pre-industrial times according to the ECHAM5 projections.

Forced by SRES scenario A1B: Around the year 2050, which leads to a representative 30-year period of 2036-2065.

Forced by SRES scenario A2: Around the year 2055, which leads to a representative 30-year period of 2041-2070.

Forced by SRES scenario B1: Around the year 2065, which leads to a representative 30-year period of 2051-2080. 


\subsection{Temperature increase on the global vs. the continental scale}

After having determined the time of the breach of the $2{ }^{\circ} \mathrm{C}$ threshold on the global level (Subsection 3.2) we now focus on Central Europe. At this stage all comparisons are still being made on the basis of the global model ECHAM5 projections forced by the three SRES emission scenarios A1B, A2 and B1. We focus on the European continent by extracting data at 12 ECHAM5 grid-points in Central Europe and computing the temperature increase for this area. For the grid resolution of the global model ECHAM5 of approximately $2^{\mathrm{O}} \times 2^{\mathrm{O}}$ in mid-latitudes these 12 grid-points cover the area of $49.43 \mathrm{~N}$ to $53.15 \mathrm{~N}$ and $7.50 \mathrm{E}$ to $13.13 \mathrm{E}$ (in decimal degrees). The positions of these grid-points are indicated by yellow crosses in Fig. 6 (a).

In order to establish a reference value for Central Europe the procedure described in Subsection 3.1 is applied to the sub-set of these 12 grid-points. Fig. 4 displays the development of the annual temperature for the time 1860-2000 for Central Europe.

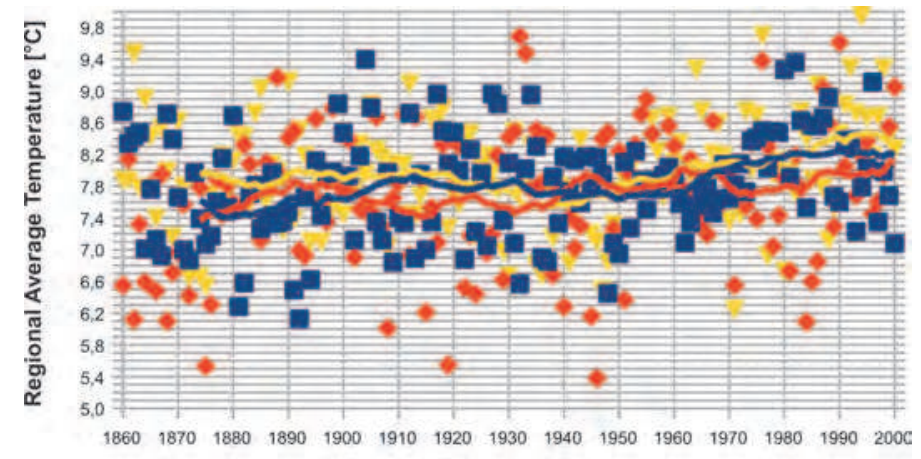

$$
\begin{gathered}
\text { Simulated Year } \\
\text { a Run } 1 \text { + Run } 2 \text { - Run } 3-\text { Run } 1 \mathrm{MA}-\text { Run } 2 \mathrm{MA}-\text { Run } 3 \mathrm{MA}
\end{gathered}
$$

Fig. 4. As Fig. 1, only limited to the 12 grid-points covering Central Europe.

According to the three historical runs an increase of $0.32{ }^{\circ} \mathrm{C}$ to $0.56{ }^{\circ} \mathrm{C}$ for Central European temperature can be inferred from Fig. 4. Two conclusions can be drawn from this analysis:

(i) It is striking that in the three historical runs there is more variability between the Central European temperature trends than between the global mean temperature changes (cf. Fig. 1). This reflects the fact that averaging over larger areas tends to reduce variability.

(ii) The temperature increases for Central Europe of $0.32{ }^{\circ} \mathrm{C}$ to $0.56{ }^{\circ} \mathrm{C}$ tend to be of a larger magnitude compared to the global average of $0.27^{\circ} \mathrm{C}$ to $0.37^{\circ} \mathrm{C}$ (cf. Fig. 1). This can be attributed to the fact that over land surfaces the warming is generally stronger than over the oceans, since the land has a lower heat capacity than water.

Similar to the method applied in Subsection 3.1 for the global average temperature, Fig. 5 shows a zoom on the time period 2041-2080 of the temperature change for the 12 Central European grid-points. Using the 30 year periods determined from Fig. 3 we can assess the simulation-specific Central European temperature increases for the respective 30-year periods. Tab. 1 summarizes the Central European temperature levels for the pre-industrial period (1860-1889) and the present-day climate (1971-2000) as well as the temperature levels for the time periods when the global average temperature crosses the $2{ }^{\circ} \mathrm{C}$ threshold in the different scenarios. Additionally, temperature increases are given for the 12 grid-points covering Central Europe in the ECHAM5 model with respect to the pre-industrial time 


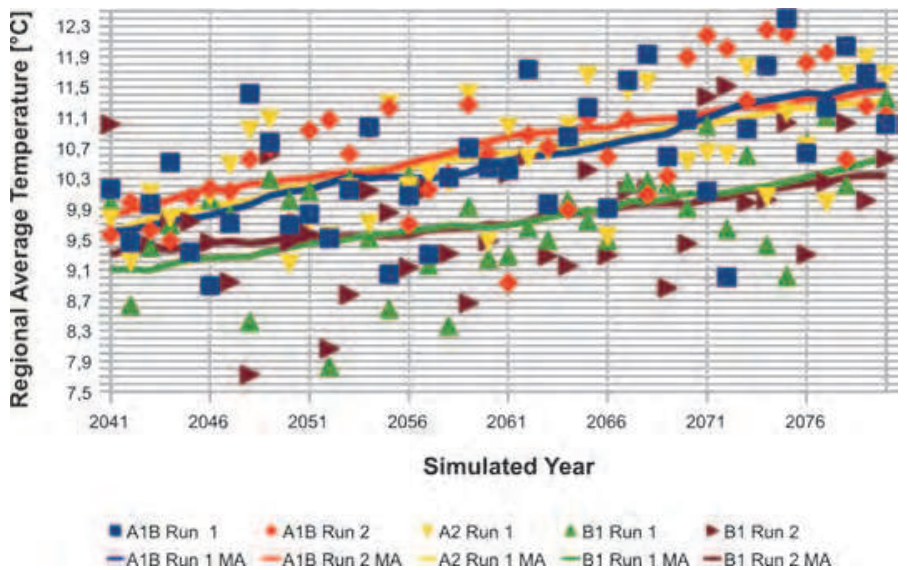

Fig. 5. As Fig. 3, only limited to the 12 grid-points covering Central Europe.

( $\Delta$ 1860-1889) and with respect to the present-day climate $(\Delta 1971-2000)$. The latter value is used to determine the warming that has already occurred from pre-industrial times until the reference period for present-day climate (1971-2000), yielding a value of $0.5^{\circ} \mathrm{C}$. Since for the regional climate simulations no pre-industrial time is available, we will add the difference of $0.5^{\circ} \mathrm{C}$ to the climate signal calculated with respect to the present-day climate, to approximate the temperature change relative to pre-industrial times.

\begin{tabular}{lccccc}
\hline Period & A1B Run 1 & A1B Run 2 & A2 Run 1 & B1 Run 1 & B1 Run 2 \\
1860-1889 & 7.62 & 7.36 & 7.62 & 7.62 & 7.36 \\
1971-2000 & 8.19 & 7.85 & 8.19 & 8.19 & 7.85 \\
\hline A1B 2036-2065 & 10.13 & 10.29 & - & - & - \\
A2 2041-2070 & - & - & 10.42 & - & - \\
B1 2051-2080 & - & - & - & 9.88 & 9.86 \\
\hline$\Delta$ 1860-1889 & 2.51 & 2.93 & 2.80 & 2.26 & 2.50 \\
$\Delta 1971-2000$ & 1.94 & 2.44 & 2.23 & 1.69 & 2.01 \\
\hline
\end{tabular}

Table 1. Annual mean temperature, computed from 12 grid-points of ECHAM5 covering Central Europe for the pre-industrial period (1860-1889), the present-day reference period (1971-2000) and for the scenario-specific periods (according to Subsection 3.1, i.e., the time of the breach of the global $2{ }^{\circ} \mathrm{C}$ threshold). The change signals with respect to the pre-industrial and to the present-day temperature are also given.

It can be concluded that the temperature increases as determined at 12 Central European grid-points of ECHAM5 are slightly higher $\left(2.3\right.$ to $\left.2.9^{\circ} \mathrm{C}\right)$ compared to the global average warming of $2{ }^{\circ} \mathrm{C}$ at these times.

\subsection{Approximating the $2{ }^{\circ} \mathrm{C}$ target for Hesse from downscaled SRES emission scenarios}

In the next step, climate change signals are obtained from RCMs (CCLM and REMO) and from the ESD WETTREG (cf. Section 2), forced by output data from the global climate model ECHAM5. In this Subsection results are displayed only for the interior of the federal state of Hesse in Central Germany [see highlighted areas in Fig. 6 (b)-(e) where, in addition, the different models' resolutions are shown]. 


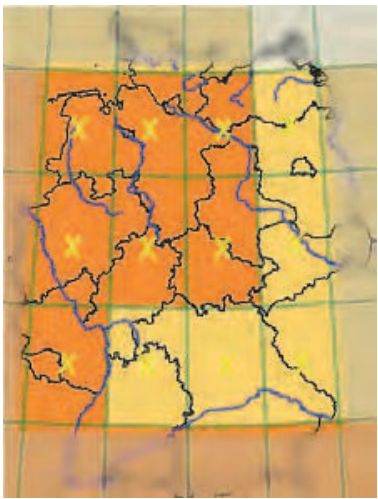

(a) ECHAM5

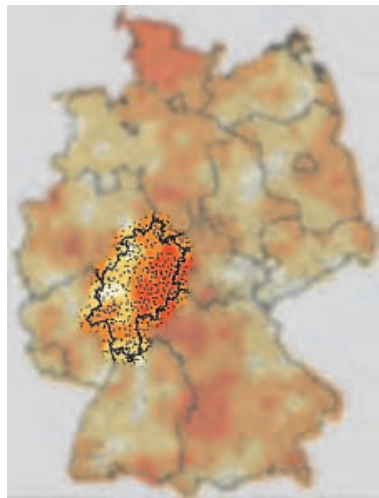

(d) WETTREG prec.

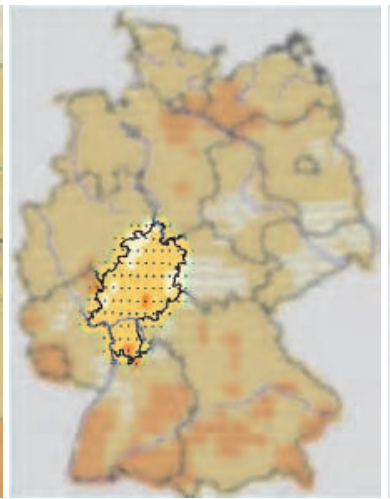

(b) CCLM

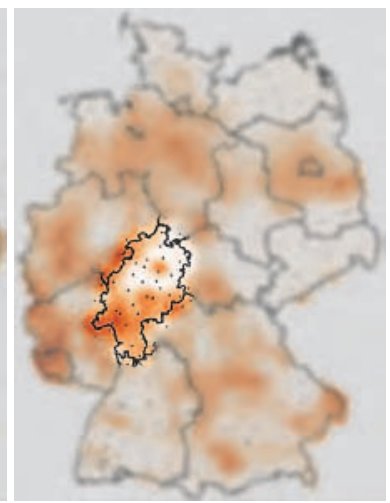

(e) WETTREG temp.

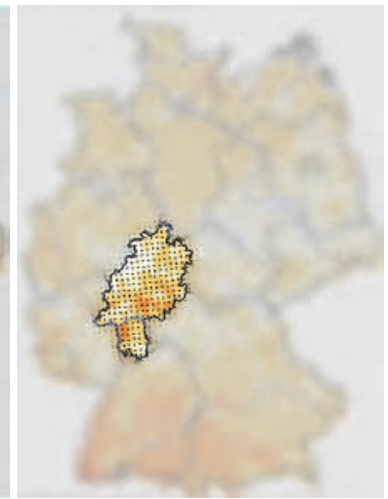

(c) REMO

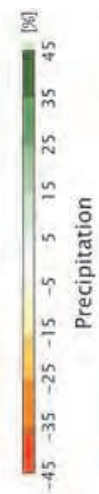

(f) Legends

Fig. 6. Resolutions of the models and method used. Subfigures (a)-(d) display the summer precipitation signal between 1971-2000 and 2071-2100 (scenario A1B). Subfigure (e) displays the respective signal of the daily mean temperature. The grid points evaluated for ECHAM5 are marked by yellow crosses in (a) and the shape of State of Hesse is indicated by the in-focus area in (b)-(e). The left-hand legend in (f) corresponds to Subfigures (a)-(d) and the right-hand legend in (f) is associated with (e). Grid points of CCLM and REMO as well as the positions of stations used in WETTREG are indicated by black dots.

In the downscaling results for the area of Hesse a slightly lower annual mean warming of 1.4 to $2.0^{\circ} \mathrm{C}$ relative to $1971-2000$ is projected (Tab. 2) compared to the temperature signal obtained for the 12 Central European grid-points from the global model $\left(1.7\right.$ to $2.4^{\circ} \mathrm{C}$, cf. Tab. 1). Taking into account the already realized warming of $0.5^{\circ} \mathrm{C}$ from pre-industrial to present-day conditions, this implies a warming of 1.9 to $2.5^{\circ} \mathrm{C}$ relative to the pre-industrial time in Hesse.

Besides annual mean temperature, some further parameters are analyzed from the regional climate model simulations. 
Regional Climate Change and Impact Assessment

\begin{tabular}{lccccc} 
Model & A1B Run 1 & A1B Run 2 & A2 Run 1 & B1 Run 1 & B1 Run 2 \\
CCLM & 1.65 & 1.98 & - & 1.41 & 1.61 \\
REMO & 1.65 & - & 1.85 & 1.38 & - \\
WETTREG & 1.34 & - & 1.64 & 1.37 & - \\
\hline
\end{tabular}

Table 2. Increase of the annual temperature on the regional scale (reference region: State of Hesse) based on the regional models CCLM, REMO and WETTREG. The temperature change signal is determined using the reference period 1971-2000 and the scenario-specific periods, i.e., 2036-2065 for A1B, 2041-2070 for A2 and 2051-2080 for B1.

When analyzing the number of heat days (daily $\mathrm{T}_{\max } \geq 30^{\circ} \mathrm{C}$ ) per year, an increase by about 6 to 10 days per year compared to the present-day period is found, indicating a doubling to tripling of current occurrence frequencies.

When analyzing precipitation changes, a seasonal shift of rainfall from the summer season into the winter season is found for the analyzed periods. Thus, even under conditions of keeping the $2{ }^{\circ} \mathrm{C}$ target summer rainfall is projected to decrease between $-16 \%$ and $0 \%$ in the area of the federal state of Hesse. Even though precipitation changes below $10 \%$ are considered not significant, the fact that all models show the same direction of trend gives a fairly clear picture of a drying trend in summer. In winter all regional model simulations show an increase of precipitation between $0 \%$ and $+29 \%$ for the area. Here, differences between the different downscaling methods (or models) are quite large: While particularly the model CCLM shows very small to no signals, the WETTREG method produces the strongest signals. However, again all models show the same general tendency, thus giving confidence in the projected trend.

The precipitation reductions in summer coincide with slightly reduced relative humidity, while for winter projected changes in atmospheric humidity are not significant. In concord with the changes in atmospheric humidity, the regional climate projections reveal slight reductions in summer cloud cover and increase in sunshine duration, but mixed results or non-significant signals in winter.

Summing up, when determining regional climate change signals from regional simulations for a time interval when the global $2{ }^{\circ} \mathrm{C}$ target is breached in SRES emission scenarios, we find the temperature increase simulated by the regional models slightly below those simulated for Central Europe by the forcing GCM ECHAM5. Precipitation shifts from summer to winter can be detected and some small changes in atmospheric humidity, cloudiness and sunshine duration can be detected from the simulation results.

\subsection{Downscaling the E1 scenario for Hesse}

In this Subsection we analyze the regional climate change signals from the GCM ECHAM5C (cf. Section 2) projections forced by the E1 scenario, i.e., an emission scenario that aims at keeping global mean warming below $2{ }^{\circ} \mathrm{C}$ (Johns et al., 2011; Lowe et al., 2009). The global simulation results are downscaled using the ESD method WETTREG. Thus, in contrast to the previous Subsections, where the time in which the global $2{ }^{\circ} \mathrm{C}$ threshold was breached was defining the periods for the analysis, we now look at the 30-year time slice at the end of the current century (2071-2100). Such an approach is independent of the temperature level, i.e., whether for this time slice the global average temperature is lower or higher than $2{ }^{\circ} \mathrm{C}$ above the pre-industrial temperature.

The so-called ring diagram in Fig. 7 (a) shows the temperature signal for the Hesse area as the result of the ECHAM5C/E1-WETTREG downscaling. Displayed is the magnitude of the temperature increase between the E1 projection for the seasonal and yearly temperature averages 2071-2100 and those for the historical simulation for 1971-2000. 


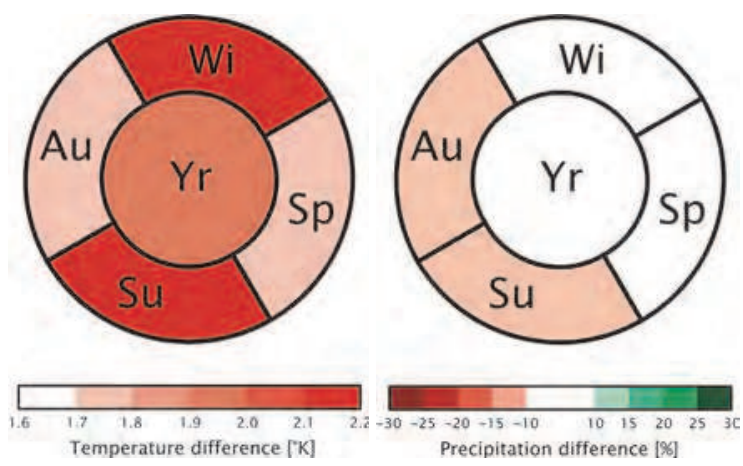

(a)

(b)

Fig. 7. Ring diagram of the increases between 2071-2100 and 1971-2000 from an average over ten WETTREG regionalizations forced by ECHAM5C/E1. The outer ring segments indicate the seasonal temperature signals [Wi: Winter (Dec.-Feb.); Sp: Spring (Mar.-May); Su:

Summer (Jun.-Aug.); Au: Autumn (Sep.-Nov.)] and the center denotes the annual value. (a): Temperature results derived from the mean of simulated series at climate stations in and around Hesse [cf. Fig. 6 (e)]. (b): Precipitation results (percentual change) derived from the mean of simulated series at precipitation stations in and around Hesse [cf. Fig. 6 (f)].

Comparing the results for the time slices in the SRES scenarios (Subsections 3.3 and 3.4) to the first results from the downscaled E1 scenario (using the statistical method WETTREG) we find that the climate signals for the period 2071-2100 relative to the reference period 1971-2000 are in the same order of magnitude for both investigations. Yet WETTREG regionalizations of the E1 scenario yield a slightly higher temperature signal which amounts to more than $1.9^{\circ} \mathrm{C}$ for the annual mean temperature and between 1.7 and $2.2{ }^{\circ} \mathrm{C}$ for seasonal average temperature values. As stated in the previous Subsection, these values require an additional $0.5^{\circ} \mathrm{C}$ correction to compensate for warming that occurred since the pre-industrial period.

As the ring diagram in Fig. 7 (b) shows, precipitation projections for the same pair of 30-year periods as above are smaller than $10 \%$ for the whole year and the winter and spring seasons. During summer and autumn precipitation decrease of more than $10 \%$ is found for this simulation. Thus, the E1 scenario with WETTREG downscaling shows a comparable drying signal in summer, but a weaker moistening signal in winter compared to the time slice results using the SRES scenarios.

\subsection{Avoidable climate change: comparing the E1-scenario with the A1B-scenario}

Finally, we present ECHAM5C results for Hesse (downscaled using WETTREG) under the higher emission scenario SRES A1B for a 30-year period at the end of this century compared to the present-day reference period. The results are juxtaposed with the respective ECHAM5C/E1 downscaling results.

From the comparison of these signals with those presented in the previous two subsections we can assess the avoidable regional climate change in Hesse. As Fig. 8 shows, the most striking difference relates to the much larger warming signal in the A1B scenario, amounting to more than $3{ }^{\circ} \mathrm{C}$ relative to $1971-2000$, while in the E1 scenario the warming in Hesse stays below $2{ }^{\circ} \mathrm{C}$.

Ten simulations of WETTREG, forced by ECHAM5C A1B and ECHAM5C E1, are also used to analyze the number of heat days, shown in Fig. 9. A large increase can be found for the 


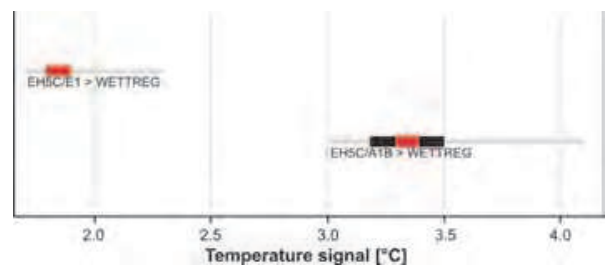

Fig. 8. Ensemble band diagram for the temperature signals (2071-2100 minus 1971-2000) derived from WETTREG regionalizations of the global model ECHAM5C results for scenarios SRES A1B (bottom) and E1 (top). Each band indicates the value range that occurs in the Hesse area. The grey part shows the entire range; the black bar displays the values between the 25 and the 75 percentile; the red bar indicates the median (the width of this bar is due to the fact that the computational accuracy of the signals is $0.1{ }^{\circ} \mathrm{C}$ ).

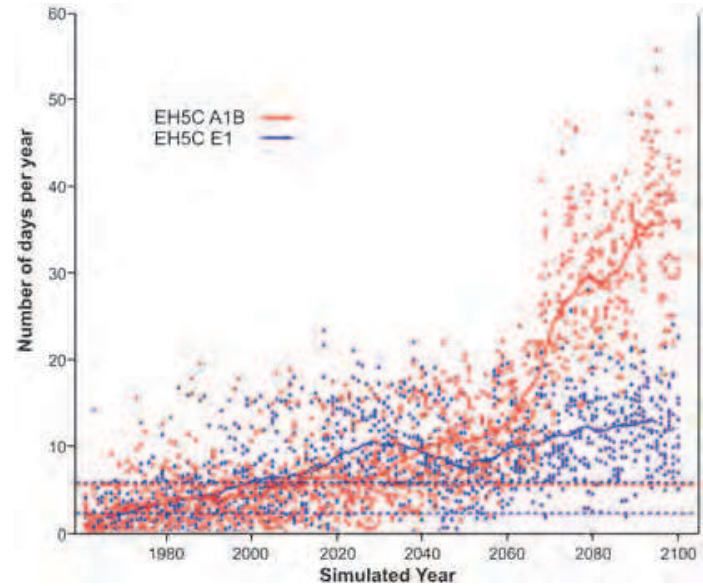

Fig. 9. Average number of heat days $\left(\mathrm{T}_{\max } \geq 30^{\circ} \mathrm{C}\right)$ per year from $1961-2100$, determined from WETTREG regionalizations forced by ECHAM5C A1B, run 1 (red) and ECHAM5C E1, run 1 (blue). The dots show the results of the ten WETTREG runs; the continuous lines indicate the 11-year running mean and the stippled lines denote the range of heat days per year, determined for the regionalizations of the period 1971-2000.

A1B scenario: In the period 1971-2000 an average of 4 days per year is detected which rises to 30 days per year in the period 2071-2100. For the E1 scenario this increase is much smaller, reaching an average of about 12 days in the period 2071-2100. Moreover, Fig. 9 shows an increase in the variability of the individual WETTREG simulations towards the end of the $21^{\text {st }}$ century for both scenarios.

Concerning precipitation change (Fig. 10) we find a similar shift in seasonal patterns in the results obtained using the two scenarios. While for winter the signals stay below $10 \%$, the change in summer is around $-10 \%$ for the E1 scenario and around $-20 \%$ for the A1B scenario in Hesse at the end of the current century. 


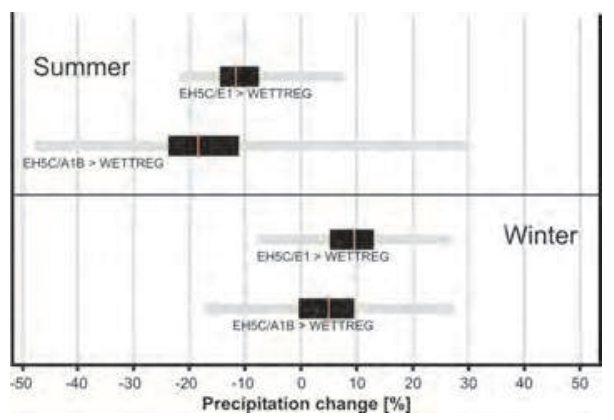

Fig. 10. As in Fig. 8 but for the precipitation change in summer (top two bands) and winter (bottom two bands). The computational accuracy of the values for precipitation change is $1 \%$.

\section{Summary and conclusions}

In the analysis presented here, we assess the regional climate change that would occur under the global $2{ }^{\circ} \mathrm{C}$ target in the federal state Hesse in central Germany. In a first approach, we approximate the situation under the global $2{ }^{\circ} \mathrm{C}$ target from time slices (30-year periods) during simulations for higher emission scenarios (SRES A1B, A2 and B1), determining the time when the global $2{ }^{\circ} \mathrm{C}$ target is breached. From this analysis we also determine that a warming of about $0.5^{\circ} \mathrm{C}$ has already occurred from the pre-industrial time until the end of the $20^{\text {th }}$ century which means that a global increase of less than $1.5^{\circ} \mathrm{C}$ over the $21^{\text {st }}$ century would be necessary to keep the $2{ }^{\circ} \mathrm{C}$ target.

In the next step we analyze the local changes in Hesse for the respective 30-year periods, centred at the time determined in the previous step. While the global model (ECHAM5) shows a significantly higher warming in the 12 grid points representing Central Europe $\left(2.3\right.$ to $\left.2.9^{\circ} \mathrm{C}\right)$ than the global mean $\left(2{ }^{\circ} \mathrm{C}\right)$, this effect is less pronounced when considering results from dynamical (RCMs CCLM and REMO) and statistical (ESD WETTREG) downscaling for Hesse. Results show, that for the respective time frames, a mean annual warming between 1.3 and $2.0^{\circ} \mathrm{C}$ (cf. Tab. 2) compared to the present-day climate reference period 1971-2000 occurs. When adding the already realized warming from the pre-industrial (1860-1889) time until $1971-2000$ of $0.5^{\circ} \mathrm{C}$ (cf. Tab. 1), we find a local warming of 1.8 to $2.5^{\circ} \mathrm{C}$ in Hesse for a global mean warming of $2{ }^{\circ} \mathrm{C}$ with respect to the pre-industrial values.

The occurrence frequency of heat days in the simulations of present-day climate (4 heat days per year) would approximately triple even if climate change could be held to a level keeping the global $2{ }^{\circ} \mathrm{C}$ target. When considering precipitation changes we find a shift of rainfall from summer to winter, a tendency that is also found in several models for different emission scenarios for Central Europe (IPCC, 2007), in conjunction with slight reductions in atmospheric moisture and cloudiness and increasing sunshine duration during summer (signals uneven or not significant for winter).

Assessment from the first available global climate model simulations for a scenario that aims at keeping the global $2{ }^{\circ} \mathrm{C}$ target at the end of the $21^{\text {st }}$ century gives similar results, even though for these simulations no high resolution dynamical downscaling results are available. The projected warming in the area of Hesse of $1.9^{\circ} \mathrm{C}$ for the end of the $21^{\text {st }}$ century in the E1 scenario relative to the present-day reference period 1971-2000 (downscaled using the ESD method WETTREG) is at the upper end of which was determined from the time slices analyzed previously $\left(1.3-2.0^{\circ} \mathrm{C}\right)$. As stated before, the value requires a $+0.5^{\circ} \mathrm{C}$ correction to compensate for warming that occurred since the pre-industrial time. 
Precipitation projections for the E1 scenario at the end of the current century show non-significant changes of less than $10 \%$ for winter and spring and decreases of $10-15 \%$ for summer and autumn, thus smaller signals than those obtained from the time slices of the SRES scenarios presented before.

In the last Subsection (3.6) we compare end-of-the-century climate change for Hesse between the SRES scenario A1B (which approximately resembles or even slightly underestimates the current emission path, cf. Le Quéré et al., 2009) and the low-emission scenario E1 (Lowe et al., 2009).

The comparison of projected temperature increase over the area of Hesse for the analyzed GCM simulation shows a significant portion of avoided warming of more than $1^{\circ} \mathrm{C}$ under the ambitious mitigation scenario E1 compared to the non-mitigation scenario A1B. Furthermore, the A1B scenario shows a large increase of heat days: On average there will be an increase in the number of heat days of about 25 heat days per year at the end of the current century relative to the present-day reference period (1971-2000). Even under the $2{ }^{\circ} \mathrm{C}$ target (scenario E1), an increase in heat days of 8 heat days per year must be expected. However, this means that two thirds of the increase simulated for the A1B scenario could be avoided when following the E1 scenario instead. This is of great concern, since heat days are typically causing heat stress with dangerous consequences: For example, in the year 2003 an excess of 16 heat days over the climatologically observed value of 6 heat days per year in the reference period led to a significant increase in mortality in Central Europe (Chase et al., 2006; De Bono et al., 2004). Additionally summer precipitation reduces under the A1B scenario by about $20 \%$ compared to a reduction of about $10 \%$ under the E1 scenario. The wintertime precipitation increase is below $10 \%$ in both scenarios.

While results between different GCMs vary (see, e.g., IPCC, 2007), they all show consistently a significant reduction of climate changes in the E1 scenario compared to the A1B scenario for the end of this century (Johns et al., 2011). It should be kept in mind, that under an emission scenario like A1B, significant further climate change beyond the year 2100 is to be expected (IPCC, 2007).

Thus, the resulting differences can be considered the avoidable climate change which would pertain to the implementation of necessary mitigation actions that lead onto a low-emission path like E1. The mitigation measures that are currently implemented, however, will lead to a much higher emission path (as in SRES A1B or higher). These avoidable changes can serve as a basis for calculating the gains from mitigation actions (in terms of avoided climate change impacts) compared to the costs of climate change impacts when no or little emission reduction is put into action.

While not for all regions of the world high resolution climate simulations are available, we show here that with some simple methods that are easy to apply and make use of data that are freely available, climate change assessments - on a continental scale - can be carried out. Further studies for a world that keeps the $2{ }^{\circ} \mathrm{C}$ target compared to the current emission path may complement and extend the studies and serve as information support for policy and economy. They are also a useful knowledge base for local stakeholders' decision making processes with respect to mitigating climate change versus adapting to the impacts of non-mitigated climate change.

\section{Acknowledgement}

The bulk of this work was funded by the Hessian Agency for Environment and Geology, Wiesbaden, Germany (Grant 4500417822). The authors also wish to thank the German Weather Service (DWD), the Max Planck Institute for Meteorology (MPI-Met), and the CCLM community for providing data and model results. NCEP Reanalysis data were 
provided by NOAA/OAR/ESRL PSD, Boulder, Colorado, USA, from their Web site at http:/ / www.esrl.noaa.gov/psd/. The ENSEMBLES data used in this work was funded by the EU FP6 Integrated Project ENSEMBLES (Contract number 505539) whose support is gratefully acknowledged. The authors are indebted to W. Enke for thinking up WETTREG. Moreover, the critical eye of C. Fooken in the development stages of this manuscript is highly acknowledged.

\section{References}

Bach, W. (1980). The $\mathrm{CO}_{2}$ issue-what are the realistic options?, Clim. Change 3: 3-5.

Berthold, G. \& Hug, H.-J. (2008). Sicherstellen der landwirtschaftlichen Produktion mit Zusatzwasserbedarf bei veränderten klimatischen Bedingungen - Maßnahmen für ein nachhaltiges Grundwassermanagement sowie Anbauempfehlungen für die landwirtschaftliche Produktion im Hessischen Ried, Project Report for "INKLIM2012, Baustein II plus" (in German). http://www.hlug.de/static/klimawandel/inklim_plus/dokumente/berichte/ zusatzwasserbedarf.pdf.

Böhm, U., Kücken, M., Ahrens, W., Block, A., Hauffe, D., Keuler, D., Rockel, B. \& Will, A. (2006). CLM - the climate version of LM: Brief description and long-term applications, COSMO Newsletter 6.

Brahmer, G., Richter, K.-G. \& Iber, C. (2008). Untersuchung der Auswirkungen des Klimawandels auf Hochwasserscheitelabflüsse und Abflussverhalten im Lahngebiet und im hessischen Maingebiet, Project Report from "INKLIM2012 Baustein II plus" (in German). http://www.hlug.de/static/klimawandel/inklim_plus/dokumente/berichte/ abfluss.pdf.

Bundesregierung (2008). Deutsche Anpassungsstrategie an den Klimawandel. (in German). http://www.bmu.de/klimaschutz/downloads/doc/42783.php.

Chase, T., Wolter, K., Pielke, Sr., R. \& Rasool, I. (2006). Was the 2003 European summer heat wave unusual in a global context?, Geophys. Res. Lett. 33: L23709. DOI: 10.1029/2006GL027470.

De Bono, A., Peduzzi, P., Kluser, S. \& Guiliani, G. (2004). Impacts of summer 2003 heat wave in Europe, UNEP Environment Alert Bulletin 2: 1-4.

Enke, W., Deutschländer, T., Schneider, F. \& Küchler, W. (2005a). Results of five regional climate studies applying a weather pattern based downscaling method to ECHAM4 climate simulations, Meteorol. Z. 14: 247-257. DOI: 10.1127/0941-2948/2005/0014-001. http:/ /dx.doi.org/10.1127/0941-2948/2005/0028.

Enke, W., Schneider, F. \& Deutschländer, T. (2005b). A novel scheme to derive optimized circulation pattern classifications for downscaling and forecast purposes, Theor. Appl. Climatol. 82: 51-63. DOI: 10.1007/s00704-004-0116-x. http:/ / www.springerlink.com/content/m737r30600222273/fulltext.pdf.

Federal State of Hesse (2011). Umweltatlas Hessen. http://atlas.umwelt.hessen.de/atlas/ > Klimawandel.

IPCC (2001). Climate Change 2001: The Scientific Basis. Contribution of Working Group I to the Third Assessment Report of the Intergovernmental Panel on Climate Change, Cambridge University Press, Cambridge, U.K. und New York, USA.

IPCC (2007). Climate Change 2007: The Physical Science Basis. Contribution of Working Group I to the Fourth Assessment Report of the Intergovernmental Panel on Climate Change, Cambridge University Press, Cambridge, UK. [S. Solomon, D. Qin, M. Manning, Z. Chen, M. Maquis, K.B. Averyt, M. Tignor and H.L. Miller (Eds.)]. ISBN 9780521 70596-7. 
Jacob, D., Göttel, H., Kotlarski, S., Lorenz, P. \& Sieck, K. (2008). Klimaauswirkungen und Anpassung in Deutschland - Phase 1: Erstellung regionaler Klimaszenarien für Deutschland. (Report), Max-Planck-Institut für Meteorologie, Hamburg.

Jacob, D. \& Podzun, R. (1997). Sensitivity studies with the regional climate model REMO, Meteorol. Atmos. Phys. 63: 119-129.

Johns, T., Royer, J.-F., Höschel, I., Huebener, H., Roeckner, E., Manzini, E., May, W., Dufresne, J.-L., Ottero̊, O., van Vuuren, D., Salas y Melia, D., Giorgetta, M., Denvil, S., Yang, S., Fogli, P., Körper, J., Tjiputra, J., Stehfest, E. \& Hewitt, C. (2011). Climate change under aggressive mitigation: the ensembles multi-model experiment, Clim. Dyn. 36: 1-29. DOI: $10.1007 /$ s00382-011-1005-5.

Kalnay, E., Kanamitsu, M., Kistler, R., Collins, W., Deaven, D., Gandin, L., Iredell, M., Saha, S., White, G., Woollen, J., Zhu, Y., Leetmaa, A., Reynolds, R., Chelliah, M., Ebisuzaki, W., Higgins, W., Janowiak, J., Mo, K., Ropelewski, C., Wang, J., Jenne, R. \& Joseph, D. (1996). The NCEP/NCAR 40-year reanalysis project, Bull. Amer. Met. Soc. 77: 437-471.

Kreienkamp, F. \& Spekat, A. (2009). Abschätzung der möglichen klimatischen Gegebenheiten auf der Basis des 2 Grad Ziels für die Region Hessen, Final Report (in German). http://www.hlug.de/klimawandel/inklim_a/dokumente/2_grad_ziel.pdf.

Kreienkamp, F., Spekat, A. \& Enke, W. (2010). Ergebnisse eines regionalen Szenarienlaufs für Deutschland mit dem statistischen Modell WETTREG2010, Climate and Environment Consulting Potsdam $\mathrm{GmbH}$ on behalf of the German Federal Environment Agency (Umweltbundesamt).

Le Quéré, C., Raupach, M., Canadell, J., Marland, G. \& Bopp, L. (2009). Trends in the sources and sinks of carbon dioxide, Nature Geosciences 2: 831-836.

Lowe, J., Hewitt, C., van Vuuren, D., Johns, T., Stehfest, E., Royer, J.-F. \& van der Linden, P. (2009). New study for climate modeling, analyses, and scenarios, EOS Trans. AGU 90: 181-182.

May, W. (2008). Climatic changes associated with a global "2 ${ }^{\circ} \mathrm{C}$-stabilization" scenario simulated by the ECHAM5/MPI-OM coupled climate model, Clim. Dyn. 31: 283-313.

Meinshausen, M., Hare, B., Wigley, T., van Vuuren, D., Den Elzen, M. \& Swart, R. (2006). Multi-gas emissions pathways to meet climate targets, Clim. Change 75: 151-194.

Nakićenović, N., Alcamo, J., de Vries, B., Fenhann, J., Gaffin, S., Gregory, K., Grübler, A., Jung, T., Kram, T., Rovere, E. L., Michaelis, L., Mori, S., Morita, T., Pepper, W., Pitcher, H., Price, L., Raihi, K., Roehrl, A., Rogner, H.-H., Sandovski, A., Schlesinger, M., Shukla, P., Smith, S., Swart, R., van Rooijen, S., Victor, N. \& Dadi, Z. (2000). Emissions Scenarios; A Special Reports of IPCC Working Group III, Cambridge University Press; Cambridge, UK.

Randalls, S. (2010). History of the $2{ }^{\circ} \mathrm{C}$ climate target, WIREs Climate Change 1: 598-605. DOI: 10.1002/wcc.62.

Rijsberman, F. \& Swart, R. (eds) (1990). Targets and Indicators of Climate Change: report of Working Group II of the Advisory Group on Greenhouse Gases, Stockholm Environment Institute.

Rockel, B., Will, A. \& Hense, A. (2008). The regional climate model COSMO-CLM (CCLM) (Editorial), Meteorol. Z. 17: 347-348.

Roeckner, E., Baeuml, G., Bonaventura, L., Brokopf, R., Esch, M., Giorgetta, M., Hagemann, S., Kirchner, I., Kornblueh, L., Manzini, E., Rhodin, A., Schlese, U., Schulzweida, U. \& Tompkins, A. (2003). The atmospheric general circulation model ECHAM5 - Part 1: Model Description, Vol. 349 of MPI-Berichte, Max-Planck-Institut für Meteorologie, Hamburg.

Roeckner, E., Brokopf, R., Esch, M., Giorgetta, M., Hagemann, S., Kornblueh, L., Manzini, E., Schlese, U. \& Schulzweida, U. (2004). The atmosphere general circulation model 
ECHAM5. Part 2: Sensitivity of simulated climate to horizontal and vertical resolution, Vol. 354 of MPI-Berichte, Max-Planck-Institut für Meteorologie, Hamburg.

Schönwiese, C.-D., Staeger, T., Steiner, H. \& Brinckmann, S. (2005). Analyse der Klimaveränderungen in Hessen für den Zeitraum 1901-2003, Report for "INKLIM2012 Baustein II" (in German). http://www.hlug.de/static/klimawandel/inklim/dokumente/endberichte/ klimaanalyse.pdf.

Schönwiese, C.-D., Staeger, T., Steiner, H. \& Brinckmann, S. (2006). Analyse der Klimaveränderungen in Hessen für den Zeitraum 1901-2003, Project Report for "INKLIM2012 Baustein II" (in German). http:/ / www.hlug.de/static/klimawandel/inklim/dokumente/endberichte/ klimaanalyse_extrem.pdf.

Smith, J., Schneider, S., Oppenheimer, M., Yohe, G., Hare, W., Mastrandrea, M., Patwardhan, A., Burton, I., Corfee-Morlot, J., Magadza, C., Füssel, H.-M., Pittock, A., Rahman, A., Suarez, A. \& van Ypersele, J.-P. (2009). Assessing dangerous climate change through an update of the intergovernmental panel on climate change (IPCC) "reasons for concern", PNAS 106: 4133-4137. DOI: 10.1073_pnas.0812355106.

Spekat, A., Enke, W. \& Kreienkamp, F. (2007). Neuentwicklung von regional hoch aufgelösten Wetterlagen für Deutschland und Bereitstellung regionaler Klimaszenarios auf der Basis von globalen Klimasimulationen mit dem Regionalisierungsmodell WETTREG auf der Basis von globalen Klimasimulationen mit ECHAM5/MPI-OM T63L31 2010 bis 2100 für die SRES-Szenarios B1, A1B und A2 (Final Report)., Climate and Environment Consulting Potsdam $\mathrm{GmbH}$ on behalf of the German Federal Environment Agency (Umweltbundesamt). http://www.umweltdaten.de/publikationen/fpdf-1/3133.pdf.

Spekat, A., Kreienkamp, F. \& Enke, W. (2010). An impact-oriented classification method for atmospheric patterns, Phys. Chem. Earth 35: 352-359. DOI: 10.1016/j.pce.2010.03.042.

Trenberth, K.E., Jones, P.D., Ambenje, P., Bojariu, R., Easterling, D., Klein Tank, A., Parker, D., Rahimzadeh, F., Renwick, J.A., Rusticucci, M., Soden \& Zhai, P. (2007). Observations: Surface and Atmospheric Climate Change. In: Climate Change 2007: The Physical Science Basis. Contribution of Working Group I to the Fourth Assessment Report of the Intergovernmental Panel on Climate Change. Cambridge University Press; Cambridge, UK.

UNFCCC (2011). Report of the Conference of the Parties on its sixteenth session, held in Cancun from 29 November to 10 December 2010. Addendum. Part Two: Action taken by the Conference of the Parties at its sixteenth session, Document identification: FCCC/CP/2010/7/Add.1. http:/ / unfccc.int/resource/docs/2010/cop16/eng/07a01.pdf.

van der Linden, P. \& Mitchell, J. (eds) (2009). ENSEMBLES: Climate Change and its Impacts: Summary of research and results from the ENSEMBLES project., Met Office Hadley Centre, FitzRoy Road, Exeter EX1 3PB, UK.

van Vuuren, D., den Elzen, M., Lucas, P., Eickhout, B., Strengers, B., b. van Ruijven, Wonink, S. \& van Houdt, R. (2007). Stabilizing greenhouse gas concentrations at low levels: An assessment of reduction strategies and costs, Clim. Change 81: 119-159. DOI: 10.1007/s10584-006-9172-9.

WBGU (1995). Scenario for the derivation of global $\mathrm{CO}_{2}$-reduction targets and implementation strategies. Statement on the occasion of the First Conference of the Parties to the Framework Convention on Climate Change in Berlin. P. 7. http://www.wbgu.de/en/publications/special-reports/special-report-1995/. 


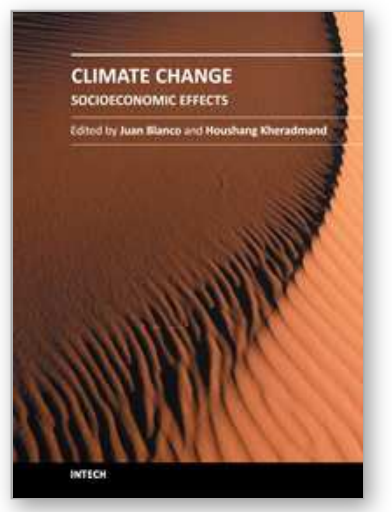

\author{
Climate Change - Socioeconomic Effects \\ Edited by Dr Houshan Kheradmand
}

ISBN 978-953-307-411-5

Hard cover, 454 pages

Publisher InTech

Published online 09, September, 2011

Published in print edition September, 2011

This book shows some of the socio-economic impacts of climate change according to different estimates of the current or estimated global warming. A series of scientific and experimental research projects explore the impacts of climate change and browse the techniques to evaluate the related impacts. These 23 chapters provide a good overview of the different changes impacts that already have been detected in several regions of the world. They are part of an introduction to the researches being done around the globe in connection with this topic. However, climate change is not just an academic issue important only to scientists and environmentalists; it also has direct implications on various ecosystems and technologies.

\title{
How to reference
}

In order to correctly reference this scholarly work, feel free to copy and paste the following:

H. Huebener, S. Baumgart, N. Jansky, F. Kreienkamp, A. Spekat and H.Wolf (2011). Regional Climate Change and Impact Assessment for the Federal State Hesse, Germany, and Implications of the Global $2{ }^{\circ} \mathrm{C}$ Climate Target, Climate Change - Socioeconomic Effects, Dr Houshan Kheradmand (Ed.), ISBN: 978-953-307-411-5, InTech, Available from: http://www.intechopen.com/books/climate-change-socioeconomic-effects/regionalclimate-change-and-impact-assessment-for-the-federal-state-hesse-germany-and-implications-o

\section{INTECH}

open science | open minds

\section{InTech Europe}

University Campus STeP Ri

Slavka Krautzeka 83/A

51000 Rijeka, Croatia

Phone: +385 (51) 770447

Fax: +385 (51) 686166

www.intechopen.com

\section{InTech China}

Unit 405, Office Block, Hotel Equatorial Shanghai

No.65, Yan An Road (West), Shanghai, 200040, China

中国上海市延安西路65号上海国际贵都大饭店办公楼 405 单元

Phone: +86-21-62489820

Fax: +86-21-62489821 
(C) 2011 The Author(s). Licensee IntechOpen. This chapter is distributed under the terms of the Creative Commons Attribution-NonCommercialShareAlike-3.0 License, which permits use, distribution and reproduction for non-commercial purposes, provided the original is properly cited and derivative works building on this content are distributed under the same license. 